\title{
VIDEO-TAPE AND OTHER MEDIA IN F. L. TEACHER TRAINING
}

by Arno G. Preller

The increased use of multi-media in the foreign language classroom is in most cases still not being reflected in our methods classes. Many education departments offer a course in the use of audio-visuals or at least devote part of their general methods course to this topic, but for the most part these courses are very theoretical and most foreign language student teachers have had little or no instruction in the specific use of media in the foreign language classroom. The special methods courses in the teaching of foreign languages must be re-examined to assure sufficient familiarity with the proper use of media. The instructor of such a class must demonstrate the use of all the media suitable to the teaching of foreign languages: he must provide opportunities for the student to actually operate the equipment, and he must constantly make use of multi-media in his own presentations in order to practice what he preaches.)

Why is the current stress on the meaningful usage of media in most special methods classes so inadequate? One reason is that the methods instructor all too often does not use media effectively in his own language classes due to his lack of familiarity with the available equipment. Another reason is that at many universities audio-visual aids are on hand but not easily accessible. The methods professor has to teach his class in whatever room is assigned to him and in many cases finds it physically impossible to transport all of the equipment which he should have.

The instructor of the "Methods of Teaching Languages" class at Colorado State University has an enviable physical set-up. He teaches his class in a special audio-visual wing. This wing is completely round and divided into a number of pie-shaped classrooms and lecture halls of various sizes. The hallway and staircase constitute the outside of the circle, so that students enter the classroom from the back. The front of each room is toward the center of the circle. The center of the circle is the service and projection area to all of the rooms on any given floor. Each of these areas is reached by elevator or stairway from the basement which houses the audio-visual department with its equipment center, TV studios, and video-tape center. In the front of 
each room is a rear-projection screen, and in the service area behind each screen a movie projector, a slide projector and a TV projector are installed. Since this projection area services all rooms on one floor, all of these projectors can easily be handled by one technician. Once the projectors are loaded, the instructor can start and stop them by using an arrangement of buttons on the lectern. With the projectors in a separate room, there are no projection noises to distract from the presentation and the room does not need to be dark, thus facilitating note-taking during the viewing of films. From the lectern the instructor can also electrically lower and raise a large white screen for use with the overhead projector which is permanent standard equipment of the room.

Several TV sets are fastened to the sides of the room for easy viewing from all seats. On the back of the room and on each side a TV camera is permanently installed. The direction of those three cameras is controlled at a console in the back of the room.

Each student of the special methods class must present a number of micro-teaching-units. These presentations are video-taped with the instructor directing the cameras from the console. This direction is a very simple process. Special viewing screens built into the console show the instructor the exact viewing field of each camera. He controls the direction, zooming and focusing of each camera. The actual taping is done in the basement by remote control. The instructor is in touch with the audio-visual department by telephone. Since each camera is equipped with a zoom lens, it is possible to show the entire classroom or to zoom in on the demonstrating student or any part of him, such as his hands.

The writer has found it helpful to keep one camera directed on the audience, one on the equipment of the room and one on the demonstrating teacher. Obviously this type of arrangement lends itself beautifully toward interaction analysis.

The tape is available for immediate playback. After a teaching demonstration the future teacher is criticized by the rest of the class and the instructor. After the class has been dismissed, the instructor and the student view the tape. The class discussion and the instructor's comments give the student specific points to look for. Without this commentary the viewing can be little more than amusing entertainment or else shock treatment. With it the student can easily see why his directions were vague, how his hand signals need improving and to what degree his class had a chance to participate. It is helpful if the student repeats the same presentation a few days later. This is time well spent since much learning occurs in the process.

If this kind of recording is done regularly throughout the course, the future teacher gets used to having his work analyzed objectively. 


\section{Video-Tape}

So that he may continue this type of self-analysis, a portable videotape recorder should be brought to class to be handled by the students for their own interaction analysis. The public schools of Colorado have video-tape centers available throughout the state, so that teachers who are properly trained in the use of this equipment have relatively easy access to it if they wish to use it to analyze and improve their teaching. Portable video-tape units should also be used for observations of student teachers. The benefits of such taping is twopronged: 1) it provides a reasonably objective means for self-criticisin and 2) it encourages the student teacher to continue this type of analysis even after he gets his permanent teaching assignment, plus encouraging by example the increased use of multi-media.

Before a student goes out to student teach, he must have the opportunity to actually use an overhead projector, opaque projector, movie and slide projectors, flannel board and other prepared visuals in a teaching situation. All of these media must be used in some of the micro-teaching units presented during the special methods class. Many beginning teachers are actually afraid to use some of the equipment simply because they have not been properly exposed to it.

Perhaps the most common tool of the foreign language teacher is the tape recorder. This tool should not be taken for granted. Most teachers do not begin to exhaust the many uses to which it can be put. The professor of the special methods class should allot a large block of time to the workings of the tape recorder. With several recorders brought into the classroom, students should thoroughly practice the manipulation of the machine including its cleaning. They should learn how to handle the tape, how to splice, erase, and how to copy by use of a patch-cord.

An expansion of a unit on the tape recorder leads logically to the language laboratory. The methods teacher cannot possibly anticipate the exact type of laboratory which his students will encounter. Then he must prepare them for a number of contingencies. Students should be made thoroughly familiar with the different types of labs used and the advantages and disadvantages of each. They must understand the differences of principle involved in library versus group facilities. They should be able to differentiate between audio-passive, audio-active and audio-active-record, as well as more recent innovations such as dialaccess and other remote-control installations. The writer is making an effort to travel throughout the state and to make slides and video-tape recordings of all types of language laboratories in use. The recordings include interviews with lab-directors, teachers, and students discussing the kind of use made of each facility and their satisfaction or dissatisfaction with various features of the installation. These tapes and 
slides are shown to the methods class. This kind of preview greatly enhances the confidence of beginning student teachers. An additional very practical way to prepare student teachers is to require a minimum of ten hours working experience in the university language laboratory under close supervision of the lab director. This is done as part of the special methods class.

All of these activities are designed to instill in the student the attitude that all the media are just as natural teaching tools as the text book. By the time the student is ready for student teaching, the incorporation of multi-media in his planning should be natural instead of an afterthought. During this observation, the supervisor of student teachers should be alert to detect the use of media as gimmicks, perhaps to impress the supervisor. The stress throughout the teacher training program should be on planning of an intelligent use of media. ABOUT THE AUTHOR:

Amo G. Preller is an Associate Professor of Languages and Education at Colorado State University. 